\title{
Relative Wages, Rationality, and Involuntary Unemployment in Keynes's Labor Market
}

Kevin D. Hoover

I don't like that book. It's not a very congenial book to read. . . . I find it carelessly written, not especially gracefully written, sometimes dishonestly written. - Robert E. Lucas, Jr. in The New Classical Macroeconomics: Conversations with the New Classical Economists and Their Opponents, by Arjo Klamer

Keynes was a lucid and resourceful master of English prose, as were Smith, Bentham, Malthus, the two Mills, Marshall and Veblen. Ricardo possibly excepted, no one of great importance in the history of Englishspeaking economic thought was otherwise. The General Theory of Employment Interest and Money, however, is a complex, ill-organized and sometimes obscure work, as Keynes himself recognized. —John Kenneth Galbraith, Economics in Perspective: A Critical History

The reputation of John Maynard Keynes's General Theory of Employment, Interest, and Money as a badly written book is often exaggerated. But if it is deserved at all, it is because of parts such as chapter 2, "The Postulates of the Classical Economy." Half a century of exegesis and interpretation have yet to provide a satisfactory and widely accepted ver-

Correspondence may be addressed to Professor Kevin D. Hoover, University of California, Davis CA 95616 or by e-mail to (kdhoover@ucdavis.edu). An earlier version of this paper was presented at the History of Economics Society meetings in Lexington, Virginia, 23-25 June 1990. I thank Thomas Mayer, Nancy Wulwick, Mark Perlman, Steven Sheffrin, William Darity, Axel Leijonhufvud, Victoria Chick, Bradley Bateman, Michel de Vroey, Don Patinkin, and an anonymous referee for helpful comments on earlier drafts.

History of Political Economy 27:4 (C) 1995 by Duke University Press. CCC 0018-2702/95/\$1.50 
sion of what this chapter really means. Reactions to chapter 2 fall into four main strands.

One strand holds that Keynes cared very little for the analysis of aggregate supply, which is the heart of this chapter, and that he rather botched the job in an effort to get on more quickly to the analysis of aggregate demand, which constitutes the bulk of the book and is its main innovation. This view draws some support from Keynes's confession to Jacob Viner that "this part of my book is particularly open to criticism" (1937, 210).

The second strand is related to the first. Some modern commentators stress that Keynes's essential insight and innovation was his analysis of aggregate demand (for example, Patinkin 1982, chap. 5, 1987; Tobin 1992). Some (for example, Patinkin) recognize that Keynes's analysis of aggregate supply also faces interpretive problems. Still others do not regard his analysis of aggregate supply as problematic but rather as fundamentally insightful and relevant, posing no great interpretive puzzles. The difficulty with this untroubled point of view is not that it is wrong about Keynes's priorities or innovations, but that it fails to appreciate fully the strength of the more hostile reactions to chapter 2 and the need to provide greater clarification of Keynes's analysis.

Both the first and second strands are too facile, for the very generality of The General Theory hinges on Keynes's dissent from the classics. It takes pride of place as the first substantial chapter of the book; and it forms the linchpin of his economic system. It is here that he tries to justify his crucial assumption that money wages do not necessarily move in such a way as to clear the labor market. And it is here that he formulates the now customary tripartite division of unemployment into voluntary, frictional, and involuntary unemployment.

A third strand is represented by authors such as William Darity and Bobbie Horn (1987a, 1987b), Michael Lawlor, Darity, and Horn (1987) and Michel de Vroey (1991), who all argue that chapter 2 is essentially a mistake. These authors draw a distinction, to use de Vroey's terminology, between labor rationing, which is the subject of chapter 2, and underemployment equilibrium, which is the real subject of The General Theory. The labor market clears in an underemployment equilibrium: labor (and other resources) are fully but not efficiently employed. An increase in aggregate demand that redirects "malemployed" resources (again, de Vroey's term) to better uses increases output and total employment. According to this view, chapter 2 could be omitted from The 
General Theory, rendering Keynes more consistent and freeing up the resources devoted to sorting out the hopelessly tangled skein of its argument.

In contrast, a fourth strand of interpretation is that non-market-clearing money wages and involuntary unemployment ultimately depend in Keynes's system on irrationality. ' Workers, it is said, suffer from "money illusion." This view is important as an early reaction to The General Theory. Economists have never been at home with irrationality, and lately it has become anathema, not only to the direct heirs to the classical tradition but also to those who see themselves as the heirs to Keynes. This view has renewed its lease with the rise of the new classical macroeconomics. Robert Lucas has gone so far as to argue that the concept of involuntary unemployment is vacuous and that it draws a distinction with no counterpart in the real world. And, as Alessandro Vercelli says, "after all, if Keynes were writing The General Theory in the eighties he would probably have chosen Lucas rather than Pigou as his Turk's head" $(1991,243)$.

This article reconsiders chapter 2. My method is to provide a close reading of that chapter. The central result of that reading is to take seriously Keynes's repeated claim that workers are concerned with their wages relative to other workers. I argue that concern for relative wages is not a secondary matter in Keynes's analysis, as some commentators suggest, but is, in fact, fundamental. The issue presents to me a series of questions: does the relative-wage argument make sense? does it obviate the need to appeal to money illusion? what is its place in Keynes's system? To answer these questions I develop a rational reconstruction of Keynes's argument in a modification of the now-familiar efficiency-wage model.

It is important to recognize that the model developed in this rational reconstruction is not an attempt to lay hold of the mantle of Keynes for the efficiency-wage model, a central element in the so-called New Keynesian Macroeconomics. New Keynesian efficiency-wage models are either real-wage models in which demand-side policies are ineffective or models that explicitly rely on money illusion to yield efficacious aggregatedemand policies. Thus, although the efficiency-wage model provides some ready-made structure on which to hang Keynes's arguments, far from stretching to find antecedents that validate the "Keynesian" roots of

1. To argue, as I shall presently, that Keynes does not assume money illusion is itself nothing new in the interpretation of Keynes. It is well worth restating this shopworn point since the error of attributing adherence to money illusion to Keynes persists after nearly sixty years. 
the efficiency-wage model, it is closer to the truth to see Keynes's analysis as suggesting ways to improve and develop an otherwise non-Keynesian model.

One objection might be that rational reconstructions of this sort are not really history. ${ }^{2}$ To which I might then reply, "Why draw such overnice distinctions if such exercises are nevertheless informative about the structure of Keynes's argument?' Interestingly, however, the method is explicitly endorsed by Keynes himself. In a letter to Ralph Hawtrey, Keynes writes, "Anyhow, the essential point is that my discussion of the classical theory of interest is merely an attempt to make an hypothesis as to what the classical theory must be if it is to be consistent with their general views" $(1973,25)$. As Keynes was to classical interest rate theory, so is my reconstruction to the analysis of the Keynesian labor market.

The model developed below is cast in a modern-looking guise, but the question it seeks to answer is this: what did Keynes think the labor market had to be like in order for it to be consistent with his general views? The model I propose is justified step by step by Keynes's insights and it generates unemployment exactly in the circumstance in which aggregate demand is inadequate. It reproduces the relationships between nominal wages, prices, and real wages found in the early chapters of The General Theory. While the model is an attempt to explicate the relativity argument of chapter 2, it is not inconsistent in any fundamental way with Keynes's more complete analysis of wage and price behavior in chapter 19. The fact that I try to understand chapter 2 and its role in the whole story does not in any way imply a devaluation or failure to appreciate the rest of the book, especially Keynes's analysis of aggregate demand and chapter 19.

The power of my interpretive strategy lies in the way in which it helps to sort through the four strands of interpretation already identified. The complacency of the second strand should surely be shattered by the recognition that the proponents of the third and fourth strands do not accept the coherence of chapter 2. Proponents of the third strand, from Leontief through Friedman and Lucas to the real business-cycle modelers, cite an inadequate analysis of aggregate supply as the principal reason for rejecting Keynes's analysis. The new classical macroeconomists, the intellectually dominant school of macroeconomics today, see this as the principal cleavage between themselves and Keynesians. It would be use-

2. This is the essence of Don Patinkin's view of the methodology of the current article (Patinkin, personal communication to author, 13 August 1992). 
ful to know if Keynes can be justly convicted of the flaw that they think that they have located in his analysis. The purpose of this article is to show that he cannot be so convicted. The proponents of the fourth strand do not dismiss Keynes as the new classicals do, but still do not find chapter 2 consistent within itself or with the rest of The General Theory. I think that it is both. Therefore my purpose, and my only purpose, is to clarify chapter 2 and to demonstrate how it hangs together. I do not promote a modern model for its own sake-certainly not the breadand-butter efficiency wage model that, despite similarities to my model, misses Keynes's point as surely as do the new classicals. To the extent that my interpretive strategy succeeds, that is to the extent that Keynes's analysis is shown to be coherent and to serve the main purposes of the rest of The General Theory, the skepticism of the first interpretive stand can be rejected as well.

\section{Keynes's Dissent from the Classics}

To place the importance of Keynes's relative-wage argument, it is useful to begin on familiar ground. Keynes characterizes the classical theory of employment-indeed, the core of classical economics-as resting on two fundamental postulates:

I. The wage is equal to the marginal product of labor.

II. The utility of the wage when a given volume of labor is employed is equal to the marginal disutility of that amount of employment. $(1936,5)^{3}$

The first classical postulate is stated more exactly as the money wage is equal to the value of the marginal product of labor. The second can be put into more modern terminology: the real wage is equal to the marginal rate of substitution between consumption goods and leisure. ${ }^{4}$

Keynes accepts the first classical postulate at least for purposes of argument $(G T, 17)$. The heart of his dissent from the classics is that he rejects the second classical postulate, except as a limiting case that defines full employment $(7-13,15,28)$. Keynes gives two reasons for rejecting the second postulate. The first is that the actual attitude of workers is such that the money wage as well as the real wage may be important

3. Hereinafter references to Keynes 1936 will appear as $G T$.

4. Keynes's statement of postulate II is inexact. He surely means the marginal utility of the wage, rather than the utility of the wage (see Fender 1981, 14 n. 1). 
to them (8-10), although he says this is not a fundamental reason. The second reason, which he does say is fundamental, is that wage bargains are made in terms of money wages, so that even if workers accept cuts in money wages these may not result in cuts in real wages or lead to greater employment (10-12).

Presently, I will consider Keynes's reasoning in greater detail. For the moment, consider just one aspect: Keynes argues that workers are concerned not only with what their wages will buy but also with their relative position with respect to other workers (13-15). ${ }^{5} \mathrm{~A}$ cut in one worker's (or a group of workers') money wages, if other workers' wages remained unchanged, would erode his (or their) relative position. Because cuts are seldom uniform, individual workers or groups have reason to care about their money wages independent of their real wages.

Keynes's argument about relativities has typically been associated with his non-fundamental objection to the second classical postulate: namely, that the actual attitude of workers is concern for nominal wages. Since I will argue in due course that it is important to associate this argument with his fundamental objection (namely, that wage bargains are made in terms of money), it is critical to observe that this argument is developed in section 3 of chapter 2-following the main discussion of his two objections and well separated from the non-fundamental objection. Its place in the text is ambiguous; it is not at all clear that it refers only, or even primarily, to the non-fundamental objection.

Having rejected the second classical postulate, Keynes is in a position to introduce the concept of involuntary unemployment. His definition is commonly taken to be that a worker is involuntarily unemployed when the real wage offered similar workers in a job he is qualified to do is higher than his marginal rate of substitution between consumption and leisure: that is, he would work for the going wage, or even somewhat less, were a job offered to him. Keynes himself sometimes refers to the involuntarily unemployed as having a marginal disutility of labor below the going wage (for example, 10, 14). Nevertheless, he does not use this condition directly to define involuntary unemployment. Instead, he adopts what appears at first sight to be an extremely convoluted definition: "Men are involuntarily unemployed if, in the event of a small rise in the price of wage-goods relatively to the money-wage, both the aggregate supply of labour willing to work for the current money-wage and the aggregate 
demand for it at that wage would be greater than the existing volume of employment" (15).

John Nicholas Smithin (1987) and Victoria Chick (1987, 72, 73) demonstrate clearly that this definition implies the well-known inequality between the real wage and the marginal rate of substitution for consumption and leisure. I will argue presently that, far from being convoluted, Keynes's definition is perfectly adapted to answer the classical objection that all unemployment is really voluntary, which has recently been forcefully restated by Lucas and other members of the new classical school.

\section{Some Standard Interpretations}

Interpretations of Keynes's dissent from the classics that center on aggregate demand (for example, Hicks [1937] 1967; Friedman 1974) to the contrary notwithstanding, Keynes's own claims in chapter 2 (and chapters 3 and 18) suggest that an acceptable interpretation should center on aggregate supply and the labor market. This by no means denies that Keynes's greatest innovations may have been in the area of aggregate demand, as Patinkin, for example, maintains (1982, chap. 5; 1987). Rather, it underlines that an economy with a Keynesian aggregate demand sector and a classical aggregate supply sector would nevertheless not deliver characteristically Keynesian behavior. Critics such as Patinkin do not deny this point; but they do take the adequacy of Keynes's labor market analysis for granted. A long interpretive tradition questions its adequacy. It is to those critics that I now turn.

\subsection{Money Illusion}

Invoking such passages as "within a certain range the demand of labour is for a minimum money-wage and not for a minimum real wage" (GT, 8), Leontief (1936) interprets Keynes as assuming the supply function for labor is not homogeneous of degree zero in prices and wages or, in the common parlance, that workers suffer from "money illusion." Because they do not understand the effect of prices on real wages, they willingly supply labor when real wages fall because of a rise in prices, although they withdraw it when real wages fall because of a cut in money-wages. This interpretation still retains great currency in textbooks of macroeconomics and the history of economic thought (see, for example, Blaug 1985, 66365; compare to note 1 above). 
Leontief notes that the homogeneity postulate is not simply assumed in classical economics but is derived from more fundamental assumptions, which, he believes, Keynes does not directly attack. The fundamental assumption that delivers homogeneity is the rationality of the worker: workers maximize utility derived from real goods subject to budget constraints. ${ }^{6}$ Leontief can be read, therefore, as asserting that Keynes assumed workers to be irrational. Professional unease with the foundations of Keynesian economics is reflected in the widespread acceptance of Leontief's interpretation: rationality is the keystone of economic analysis.

While it is clear that Keynes was willing to entertain the possibility that workers sometimes act under money illusion, this was not essential; and he took pains to claim that his argument works when workers are fully rational $(G T, 9,14) .^{7}$ Beyond this, however, all passages that seem to support the interpretation based on money illusion refer to Keynes's non-fundamental objection to the second classical postulate. In other words, even under the best case for his critics, money illusion in Keynes's own view could not be theoretically fundamental, whatever its practical importance.

\subsection{Rigid Wages}

Blaug $(1985,663)$ asserts that the importance of money illusion is as an explanation for wage rigidities. He goes on to claim that any other source of rigidity, such as powerful trade unions or minimum wage laws, will do just as well to support the Keynesian model of income determination. Whatever the merits of these claims with respect to income determination, it is clear that trade unions, minimum wage laws or, for that matter, money illusion will not support Keynes's analysis of involuntary unemployment. Keynes $(G T, 5,8,16)$ concedes to the classics that unemploy-

6. This construes "rationality" in an extremely narrow sense, one completely appropriate to the nature of the issues addressed in this paper but one far too narrow to do justice either to Keynes's rich epistemology or to recent Keynesian scholarship (cf. Carabelli 1988 and Bateman 1987).

7. Some evidence to the contrary might be found in the introduction to Keynes's reply to his critics $(1937,209)$ in which he concedes the theoretical correctness of Leontief's point. I do not think that this should be taken too seriously as Keynes never develops his "concession" in that paper or, I think, elsewhere. In this case, he really does seem to want to push quickly through the discussion of aggregate supply to get on with the theory of investment and interest, which are his chief concerns on that occasion. 
ment resulting from obvious market imperfections such as trade unions, closed shops, and minimum wage laws is rightly classified as voluntary.

That unemployment due to money illusion is also voluntary can be inferred from Keynes's discussion of the second classical postulate. "Disutility [of labor]," he writes, "must be here understood to cover every kind of reason which might lead a man, or a body of men, to withhold their labor rather than accept a wage which had to them a utility below a certain minimum" (6). Money illusion renders the labor supply curve nonhomogeneous; but so long as the supply of labor actually forthcoming is determined on the labor supply curve-homogeneous or not-unemployment is voluntary.

Whatever justification might be given for rigid wages, it is clear that Keynes did not mean his theory to depend upon them. To be sure, he assumes that money wages are fixed in chapter 3 but only with the caveat that this is a simplification to be relaxed in due course (27). And chapter 19 is entitled "Changes in Money-Wages."

\subsection{Heterogeneous Goods}

The obvious alternative to concentrating on Keynes's non-fundamental objection as the arguments from money illusion and fixed money wages do, is to try to make sense of his fundamental objection. Keynes denies "that the wage bargains between the entrepreneurs and the workers determine the real wage" so that "there is no longer any reason to expect a tendency towards equality between the real wage and the marginal disutility of labour" (11).

Leijonhufvud $(1968,97,98)$ argues that Keynes wants to draw a fundamental distinction between monetary and barter economies. In monetary economies, demands must be communicated through offers to pay money. A worker may desire to work at a real wage less than his marginal product, but a firm will not hire him unless it sees demand in the form of money on offer for its output. This demand cannot simply be direct barter with the worker: he cannot "feed his family on a ton-and-a-half of cold-rolled sheet a week" (90).

Leijonhufvud's argument is an application of Clower's (1965) disequilibrium analysis. ${ }^{8}$ As such, it is most appropriate to the analysis of

8. This was prefigured in Patinkin [1956] 1965. Clower himself shows some distaste for the term "disequilibrium" and for the ways in which his ideas were developed by Robert Barro and Herschel Grossman $(1971$; 1976) and others. He only reluctantly admits to being the 
quantities traded, given prices that are not market clearing. In itself, it does not explain why a firm does not cut its real wages and so reduce any gap between the real wage and the marginal disutility of labor. It is not enough to say that demand is deficient at current prices. For the output of the firm can be sold at some lower price, however small, and that price determines the value of the worker's marginal product and the demand for labor. If labor is forthcoming at the implied lower wage, the firm has every incentive to employ it; if it is not forthcoming, labor is voluntarily, not involuntarily, unemployed. ${ }^{9}$

Although Leijonhufvud's analysis is incomplete, it remains important. It is an attempt to take seriously the truth that modern economies are complex with many heterogeneous goods and that money is necessary to cope with such heterogeneity. After all, in a subsistence economy, workers eat their own output, so demand failures are not an issue.

Victoria Chick $(1987,141,142)$ also appeals to heterogeneous goods in order to interpret Keynes's fundamental objection. She points out that from the worker's point of view, the real wage depends on the prices of the many goods he consumes and not on the price of his employer's output. Surely the worker must bargain for money wages, not real wages, because the real wage cannot even be known until after the worker is paid.

While it is clear that Chick's point is correct, it is not obvious that it is enough to explain persistent, substantial deviations from full employment. Any form of indexation would be some improvement over simple money-wage bargains. Keynes could not have been unaware of various experiments with indexation (for example, those in the British coal industry just after World War I).

\subsection{Nominal Wage Adjustment}

Fender interprets Keynes's fundamental objection as an argument not about static equilibrium but rather about dynamic adjustment (Fender 1981, 20-23). The classics assume that, when the labor market is not in equilibrium, the real wage adjusts to clear the market. Fender reads Keynes as accepting the classical description of static equilibrium as a function of real wage, but as arguing that, when the labor market is not in equilibrium, the nominal wage adjusts. Since profit-maximizing prices 
are largely determined by wage costs, prices tend to fall along with falling nominal wages. The real wage may, therefore, not fall - or even rise-so that there is no tendency to clear the labor market. Fender's interpretation is supported in part in The General Theory. Keynes writes, "Thus, if money-wages change, one would have expected the classics to argue that prices would change in almost the same proportion, leaving the real wage and the level of unemployment practically the same as before" (GT, 12). In a footnote to this passage, Keynes writes, "This argument would, indeed, contain, to my way of thinking, a large element of truth, though the complete results of a change in money-wages are more complex" $(12$, n. 1); he then points the reader to chapter 19 , in which the complexity of wage/price interaction is explored. Fender recognizes that this dynamic argument is not Keynes's whole story; for he writes: "The argument is not that prices will change to exactly the same extent as money-wages, hence keeping real wages constant. The argument is rather the much weaker one that money-wage adjustments may not produce the adjustment in the real wage required to restore full-employment equilibrium" $(1981,22,23)$.

Patinkin (1982, 141-42; 1987, 27, column 2) argues, against interpretations such as Fender's, that Keynes did not find a direct causal link between nominal wages and prices but rather an incompletely specified causal chain connecting nominal wages through aggregate demand, unemployment, and the marginal product of labor (invoking the first classical postulate) to prices. Fender's argument can be seen as insufficient for another reason as well. If, as Fender supposes, the nominal wage falls when labor is in excess supply, the real wage will move toward market clearing if prices also fall less than proportionally. If they fall proportionally, the same situation of excess supply will continue; conversely, if they fall more than proportionally, unemployment will become progressively worse. In the first case, the classics would be correct: the market clears. Neither Fender nor Keynes puts stock in the second case of perfect proportionality. And there is no evidence that Keynes thought that the third case, which amounts to progressive collapse of the labor market, was in any sense general. Rather Keynes thought that "an outstanding characteristic of the economic system in which we live [is that] whilst it is subject to severe fluctuations in respect of output and employment, it is not violently unstable. Indeed it seems capable of remaining in a chronic condition of sub-normal activity for a considerable period without any marked tendency either towards recovery or towards complete collapse" $(G T, 249)$. 
Clearly, Fender is right to ascribe the dynamic argument to Keynes; but it cannot be the whole of his fundamental objection. More is needed to explain the subnormal activity that Keynes believed to be the chronic condition of many economies.

\section{The Place of the Relative-Wage Argument}

What more is needed, I believe, is attention to Keynes's oft repeatedindeed emphasized-point that it is the relative wage rate as well as the real wage rate that matters to workers: "any individual or group of individuals, who consent to a reduction of money-wages relatively to others, will suffer a relative reduction in real wages, which is sufficient justification for them to resist it" (GT, 14; compare to 252, 253, 264).

As I have already observed, whether this claim is meant to support Keynes's non-fundamental or fundamental objection to the classics is unclear. The reason, as I show presently, is that it is meant to support both objections. To associate the relative-wage argument exclusively with the non-fundamental objection, as many commentators do without adequate textual warrant, renders Keynes's argument in chapter 2 obscure and inconsistent, or simply incorrect. To associate it with the fundamental, as well as the non-fundamental, objection reveals Keynes's argument to be both consistent and richly suggestive.

\subsection{Two Confusions}

Two confusions arise from Keynes's claim for the importance of relative wages. The first is that resistance to money-wage cuts is organized through unions. ${ }^{10}$ The confusion arises because Keynes writes such sentences as: "The effect of combination on the part of a group of workers is to protect their relative real wage" $(G T, 14)$ and "Every trade union will put up some resistance to a cut in money-wages, however small" (15). But these are elaborations on a more general point. The quotation above clearly states "individuals or groups of individuals," so that any successful interpretation of Keynes's point must apply with equal force to unorganized as well as organized labor. 
The second confusion about Keynes's claims for the importance of relative wages is the belief that worker resistance should be glossed as "strikes" or "withdrawal" of labor. This would make nonsense of Keynes's analysis of involuntary unemployment; for earlier, he concedes to the classics that if people are unemployed "due to an open or tacit agreement amongst workers not to work for less, and if labour as a whole would agree to work for less more employment would be forthcoming . . . such unemployment, though apparently involuntary, is not strictly so, and ought to be included under the . . . category of "voluntary' unemployment due to the effects of collective bargaining, etc." (8). Inasmuch as the claim about the importance of relative wages is intended to explain involuntary unemployment, worker resistance cannot be entirely a matter of strikes or withdrawal of labor, as these are indicators of voluntariness. Of course the quotation also reinforces the earlier point that the claim about relative wages is not simply a claim about the behavior of unions. To put it another way, open or tacit agreements not to work for lower than current money wages modify the shape of the labor-supply schedule, but they do not cause involuntary unemployment because that requires workers to be off their labor-supply schedules.

It is clear, therefore, that, while Keynes was willing to believe that relative wages affect the labor-supply schedule, he must also have believed that they affect labor demand; otherwise the claim about relative wages lends no support to his central contention that involuntary unemployment is not only possible but important and common. Of course, if relative wages affect labor demand, they must do so, in Keynes's view, because of worker resistance. Worker resistance in turn must be construed more widely than "strikes" or other "withdrawals of labor" if the resulting unemployment is to be involuntary.

\subsection{Labor Supply}

Keynes confronts heterogeneity in the economy squarely. In introducing his claim about relative wages, he says, "there is imperfect mobility of labour, and wages do not tend to an exact equality of net advantage in different occupations" $(G T, 14)$, which is to say that he takes the heterogeneity of the labor force seriously. His model of the economy is not the single-sector model implicit in textbook IS-LM-AS "Keynesian" models. At minimum, it is a two-sector model with a capital-goods sector 
and a consumption-goods sector. ${ }^{11}$ In the same spirit, relative wages may be introduced into the labor-supply decision in order to clarify Keynes's non-fundamental objection.

The utility of a representative worker in the consumption-goods sector can be written

$$
U=U\left(C, L, w_{c} / w_{k}\right),
$$

where $C$ is consumption, $L$ is labor and $w_{c} / w_{k}$ is the ratio of the wage in the consumption-goods industry $\left(w_{c}\right)$ to the wage in the capital-goods industry $\left(w_{k}\right)$. The labor-supply schedule can be derived in the usual way: the worker chooses consumption and leisure, taking wage rates as given, subject to the budget constraint,

$$
w_{c} L-p_{c} C=0,
$$

where $p_{c}$ is the price of the consumption good. The resulting labor-supply schedule will, in general, have the form

$$
L^{S}=f\left(w_{c} / p_{c}, w_{c} / w_{k}\right)
$$

that is, labor supply depends (directly) on the real wage (as judged by the worker) and (directly) on relative wages.

A property of the labor-supply function with relative wages is that if the labor supply is plotted against real wages then, holding $w_{k}$ constant, any change in $w_{c}$ will shift the entire curve. Fender $(1981,17,18)$ makes a similar observation to confirm Keynes's statement that when the laborsupply curve is a function of nominal wages, "the supply curve for labour will shift bodily with every movement of prices" $(G T, 9)$. Fender must take Keynes to include "wages" in "prices" if this explanation is to make sense. Context gives no reason to suppose that Keynes in fact meant wages, especially when one follows up the reference to the appendix to chapter 19 as suggested in a footnote to this passage.

The appendix suggests an alternative interpretation consistent with relative wages in the labor-supply function. Fluctuations in investment cause fluctuations in the demand for labor in the capital-goods sector. Employment and therefore wages in the capital-goods sector $\left(w_{k}\right)$ fluctuate. This in turn causes fluctuations in the demand for and price of consumption

11. Interestingly, John Hicks's ([1937] 1967) original IS-LM model is a two-sector model. Santi Chakrabarti (1979) also stresses the two-sector nature of Keynes's model. 
goods. A change in $p_{c}$, which changes the real wage, of course leads to movements along the supply curve for labor in the consumption-goods sector. But the change in $w_{k}$, which changes relative wages, also causes the curve to shift. Thus, just as Keynes argues, the supply curve shifts with every change in prices.

Observe that when labor supply depends on relative wages, workers in the consumption-goods sector will wish to withdraw their labor when their wage falls even if prices fall proportionately, leaving the real wage unchanged. Also observe that this is fully rational in the sense of Leontief. If all prices, including all wages, change by equal proportions, then neither real wages nor relative wages are affected, so the labor supply is itself unchanged. The utility function is homogeneous of degree zero in prices and wages, and this implies that the labor-supply function is also homogeneous. Keynes's belief that no irrationality is involved in workers' concern about nominal wages is vindicated: they do not suffer from money illusion.

So far so good. Still, if employment is given as the intersection of labor supply and labor demand, even if relative wages appear in the labor-supply function, all who wish to be employed are employed; there is no involuntary unemployment. Equally, if disutility comprises all the reasons one might have to withdraw labor, equality between the supply of and the demand for labor-even if relative wages appear in the labor-supply function-rules out the real wage exceeding the marginal disutility of labor. Keynes's non-fundamental objection, interpreted as a point about the importance of relative wages in labor supply, does not then by itself explain involuntary unemployment.

Keynes claims that, when labor supply depends on relative wages, the classical labor market is indeterminate. Fender interprets this as resulting from the shifting of the labor supply curve with changes in wages (prices) as discussed above. He points out that the system is quite determinate even with a shifting labor-supply function, so that Keynes's non-fundamental objection is simply wrong, "and it is fortunate that he laid no theoretical weight on it" (Fender 1981, 18). Once again, if we follow Keynes's suggestion to consult the appendix to chapter 19, it is clear that his point is not about the shifting labor-supply function per se but about the way in which the classics achieve closure in their models by assuming that some mechanism ensures full employment $(G T, 274)$. If they are not entitled to assume this, then Keynes is correct, their labor markets are indeterminate; and, if they are entitled, then Fender is correct, the labor 
market is determinate even when relative (or nominal wages) appear in the labor-supply function.

This suggests, however, that the reason the objection is non-fundamental is that Keynes knew that it did not by itself explain unemployment. All Keynes wished to show, and all he showed satisfactorily, was that workers might rationally care about nominal wages independently of real wages. The classics have no right in Keynes's view to insist that only real wages count. It is a matter of "the actual attitude of workers towards real wages and money-wages respectively and is not theoretically fundamental" $(G T, 8)$.

Clearly the theoretical weight must rest on Keynes's fundamental objection: workers bargain for money wages, not for real wages. Workers, Keynes reiterates, resist cuts in their relative wages and, therefore, cuts in their nominal wages. As already shown, if such resistance were merely strikes or withdrawal of labor, then it would form no basis for an explanation of involuntary unemployment; yet Keynes associates worker resistance with involuntary unemployment. For this reason, if for no other, it is clear that the claim about the importance of relative wages must be associated with the fundamental objection (as well as with the non-fundamental objection).

\section{A Relative-Wage Model of the Labor Market}

What form does worker resistance take? Keynes does not go into detail, but possibilities are slowdowns, sabotage of equipment, lack of cooperation with management, or simply poor performance due to low morale, all lowering productivity. This immediately suggests the modern theory of efficiency wages. I will show that it is possible to give a consistent and complete interpretation of Keynes's fundamental objection as a relativeefficiency-wage model. $^{12}$

It may be worth reiterating that the interpretive strategy here is to use considerations explicitly discussed in The General Theory to adapt the efficiency-wage model into a vehicle to showcase important features of

12. Akerlof and Yellen 1986 (especially the introduction) and Stiglitz 1987 provide excellent introductions to efficiency-wage models. Akerlof and Yellen say that efficiency-wage models are necessarily models of the determination of the real wage (1986, 16, 17). Joseph Stiglitz $(1987,35,36)$ disagrees in principle, although he does not work out a complete nominal efficiency-wage model. Stiglitz is correct; the relative efficiency-wage model presented below explains nominal wage stickiness. 
Keynes's argument and their interrelationship. I do not argue that Keynes had (implicitly) worked out an efficiency-wage model. Rather, the model I present here is a consistent synthesis of what has appeared to some to be Keynes's incoherent discussion of the labor market.

It is perhaps useful to note that this enterprise is not entirely anachronistic or Whiggish. Alfred Marshall already uses the term "efficiencywages" to refer to work measured in efficiency units $(1920,548)$. Furthermore, he had the idea that higher real wages increase efficiency: "highly paid labour is generally more efficient and therefore not dear labour; a fact which, though it is more full of hope for the future of the human race than any other that is known to us, will be found to exercise a very complicating influence on the theory of distribution" $(1920,510)$.

Marshall (1920, 529-33 passim) seems largely, though not exclusively, to find the mechanism for increasing efficiency in nutrition and better physical conditions for workers, and to find efficiency considerations more relevant to the underdeveloped "southern clime" (cf. Leibenstein 1957). Keynes knew his Marshall. Indeed, in a letter to Hawtrey in 1936, Keynes $(1973,35)$ cites this very passage from Marshall's Principles. Marshall pervades The General Theory, even where he receives no explicit recognition. The model here differs sharply from what Keynes found in Marshall, in that it is a nominal efficiency-wage model and not a real efficiency-wage model, and in that it is used to address questions of economic fluctuations and not long-term distribution.

Keynes is careful to distinguish between consumption goods and capital or non-wage goods, and he often refers to the variety of capital goods. Keynes's analysis is multisectoral at root. A two-sector model is, therefore, the minimum appropriate to Keynesian analysis. This is already evident in the analysis of labor supply in section 3 above. Still, to discuss some of the issues involved in analyzing involuntary unemployment adequately, I will have to consider a three-sector model. I arbitrarily label two sectors as different capital-goods sectors and the third sector as the consumption-good or wage-good sector. I assume that relative wages matter only in the capital-goods sectors. One might imagine that relative wages were important to workers in every industry; Keynes, however, clearly recognized that there are degrees of bargaining power: some workers are in a better position to protect their relative wages than others (see $G T, 267$ ). To capture this insight in an extreme case, I model the consumption-goods sector in the traditional neoclassical manner: the real wage adjusts to clear the market; labor supply is always equal to 
labor demand. This has the added advantage of making the model close to many modern efficiency-wage models in which there are primary labor markets, in which efficiency wages are paid, and secondary labor markets, in which market-clearing wages are paid (for references, see Akerlof and Yellen 1986, 3, 4). It will thus be easier to discuss modern criticisms of the Keynesian definition of unemployment in the next section. Whether it is really the consumption-goods sector in which workers have the least bargaining power is of no importance in what follows.

\subsection{The Capital-Goods Sectors}

The two capital-goods sectors will be designated $k 1$ and $k 2$. I shall first present a model of sector $k 1$. Appropriately altering the subscripts gives the model for sector $k 2$.

In common with all efficiency-wage models, assume that effective labor is the product of the number of workers employed (or hours worked) and the efficiency of each worker (or hour). Let efficiency depend directly upon the perceived relative wage. Thus for $k 1$

$$
e_{k 1}=e_{k 1}\left(w_{k 1} / w_{k 2}^{P}\right)
$$

where $w_{k 2}^{P}$ is the perception of the workers in $k 1$ of the wage paid in $k 2$. There are assumed to be many firms in each sector, so that the rules for profit-maximization under perfect competition apply wherever the assumption of efficiency wages does not alter them. The short-run production function for the firm may be written

$$
y_{k 1}=f_{k 1}\left(e_{k 1} L_{k 1}\right)
$$

and is assumed to have the usual neoclassical properties, except that the labor input is now measured in efficiency units.

Taking prices and the wage in $k 2$ as given, the firm now has two means of obtaining higher output: to hire more workers or to pay higher nominal wages. The firm chooses both the wage rate and its demand for labor in order to maximize profits,

$$
\pi_{k 1}=p_{k 1} f_{k 1}\left(e_{k 1}\left(w_{k 1} / w_{k 2}^{P}\right) L_{k 1}\right)-w_{k 1} L_{k 1} .
$$

The first-order conditions for this problem are:

$$
p_{k 1} f_{k 1}^{\prime} e_{k 1}=w_{k 1}
$$


and

$$
p_{k 1} f_{k 1}^{\prime} e_{k 1}^{\prime}\left(1 / w_{k 2}^{P}\right) L_{k 1}-L_{k 1}=0
$$

or

$$
p_{k 1} f_{k 1}^{\prime} e_{k 1}^{\prime}=w_{k 2}^{P} \text {. }
$$

Optimal choices of $w_{k 1}^{P}$ and $L_{k 1}$ for given $p_{k 1}$ and $w_{k 1}$ are easily determined. ${ }^{13}$ Divide equation (4) by $\left(5^{\prime}\right)$ and rearrange to yield the "Solow condition" for this model (see Akerlof and Yellen 1986, 3):

$$
e_{k 1} / e_{k 1}^{\prime}=w_{k 1} / w_{k 2}^{P},
$$

which may be solved for $w_{k 1}^{*}$, the equilibrium value of $w_{k 1}$. Substituting $w_{k 1}^{*}$ into (4) or $\left(5^{\prime}\right)$, the equilibrium demand for labor, $L_{k 1}^{D *}$, may be recovered.

If at the real wage, $w_{k 1} / p_{k 1}$, equilibrium labor supply, $L_{k 1}^{S *}$, is greater than $L_{k l}^{D *}$, then some workers are unemployed, for Keynes assumed that the short side of the market dominates. Workers wish to work at the current wage or even somewhat less, but firms will not hire them, for any gains from additional workers at lower wages are more than offset by losses from the reduced productivity of the existing workers who suffer a drop in their relative wages.

Firms choose an optimal money-wage and will not lower it in order to employ redundant workers. On the other hand, if prices rise, holding wage rates constant, efficiency is constant, the real wage falls and firms are willing to hire more workers, just as in the standard neoclassical analysis. Again, we should notice that no irrationality in the sense of Leontief (no money illusion) is involved. If all wages (including perceived wages in the other sectors) and prices change by the same proportion, the demand for labor and the output of the firm are unaffected. Instead, Keynes provides a reason why firms are reluctant to lower the money-wages they pay in the face of given money-wages paid by other firms. If all firms feel such reluctance, wages are sticky downward, despite the fact that a coordinated wage cut might be good for all firms and for the unemployed.

It is precisely to rule out such coordination that firms are modeled as setting nominal wages and demand for labor conditional on the wage

13. The problem yields sensible solutions only if the function $e_{k 1}\left(w_{k 1} / w_{k 2}^{P}\right)$ has the proper shape (see Stiglitz 1987, 5): $e_{k 1} /\left(w_{k 1} / w_{k 2}^{P}\right)$ must first increase then decrease as $\left(w_{k 1} / w_{k 2}^{P}\right)$ increases. An example of such a function, a modification of one given by Akerlof (1982), p. 561, is $e=-a+b\left(w_{k 1} / w_{k 2}^{P}\right)^{\alpha}$, where $a, b>0$ and $0 \leq \alpha \leq 1$. 
perceived to prevail in the other sector. This specification aims to capture Keynes's view that a firm's nominal wages are sticky because workers would perceive a unilateral cut as eroding their relative position. Clearly, as Keynes points out, inflation would lower real wages without affecting efficiency. A coordinated cut in nominal wages would have precisely the same effect. One should think of firms as playing a game in which they choose their nominal wage simultaneously with other firms while ignorant of the other firms' choices. Their perception of the other firms' wages is therefore based on the last move. So long as the demand for labor is less than the supply of labor, no firm will find any advantage in being the first to raise its nominal wage, and every firm will find an efficiency loss in being perceived to have lowered its nominal wages relative to other firms. ${ }^{14}$

Actually, this is true only if the efficiency functions in the two sectors are related in a special way. To see what is at stake, imagine that each sector had an efficiency function that achieved peak efficiency only when the wage was twice what it was in the other sector. Firms would have to embark on a series of competitive wage increases to attempt to capture relative advantage. To be fully satisfactory for economic analysis, a model would have to include a mechanism through which efficiency would alter endogenously until some sort of steady-state were reached. But the purposes of the current model are expository and considerations of that dynamic process are beyond the scope of this article. It is clear from Keynes's discussion of relative wages that he imagined some sort of steady-state relative wage structure to be prevailing already. To capture this for comparative static exercises, I impose the condition that the efficiency functions in $k 1$ and $k 2$ be related in such a way that

$$
w_{k 1}^{*} / w_{k 2}^{P}=w_{k 1}^{P} / w_{k 2}^{*} \text {. }
$$

This means that the optimal relative wage in $k 1$ is precisely the inverse of the optimal relative wage in $k 2$, so that, if each sector chooses its wage based on its perception of the other sector's wage, its perception will be confirmed, and there will be no incentive to embark on a path of competitive adjustment.

14. The sticky nominal wage provides the same sort of handle for aggregate demand policies as do sticky nominal wages in models such as those in Fischer 1977 and Taylor 1979. The nominal-efficiency-wage model differs from these, however, in that it does not assume any fixed contract length. The game is played continuously, and the gap between when one firm sets its wage and when this is perceived by workers in the other firm can shrink to an infinitesimal duration, so long as changes in wages are never coordinated. 
To complete the supply side of the capital-goods sectors, assume that the supply of labor is derived from a utility-maximization problem as in section 3 above and depends on the nominal wage paid and the price of wage goods, $p_{c}$ :

$$
L_{k 1}^{S}=L_{k 1}^{S}\left(w_{k 1} / p_{c}\right) \text {. }
$$

Workers are assumed to be completely differentiated by skill, so that those employed in sector $k 1$ are never employed in $k 2$ nor those in $k 2$ in $k 1$. This is a stronger assumption than Keynes in fact makes or than is really needed, but it captures the flavor of Keynes's view of the labor market and simplifies the concrete model presented in the appendix to this paper.

So far, I have assumed that $L^{S}$ is greater than $L^{D}$. But we must add the condition that the inequality cannot be reversed. At the point at which the supply of labor just equals the demand for labor, the efficiency condition, equation (6), must be replaced by

$$
L_{k 1}^{S}=L_{k 1}^{D} \text {, }
$$

for all higher levels of demand. Essentially, this says that nominal wages will rise to clear the sectoral labor market once full employment has been reached.

Within the capital-goods sectors, this model almost agrees with the accepted explications of Keynes's analysis of unemployment: when there is unemployment, the real wage exceeds the marginal rate of substitution of consumption for leisure (or, in Keynes's own terms, the marginal disutility of labor). It differs from the accepted explication only in that the demand for labor is a particular point, not a schedule, because taking the price level as given, the fact that the firm chooses the most efficient nominal wage implies that it chooses the real wage as well.

\subsection{The Consumption-Goods Sector}

Assume that efficiency wages are not paid in the consumption goods sector. Therefore, the short-run production function for consumption goods is

$$
y_{c}=f_{c}\left(L_{c}\right) \text {, }
$$

and has the usual neoclassical properties. Profits are

$$
\pi_{c}=p_{c} f_{c}\left(L_{c}\right)-w_{c} L_{c} .
$$


A firm chooses $L_{c}$ to maximize $\pi_{c^{\prime}}$, taking $p_{c}$ and $w_{c}$ as given. This problem has the single first-order condition,

$$
f_{c}^{\prime}=w_{c} / p_{c} \text {. }
$$

The demand for labor as a function of the real wage in the capital-goods sector can be derived from inverting this first-order condition:

$$
L_{c}^{D}=L_{c}^{D}\left(w_{c} / p_{c}\right) \text {. }
$$

Keynes assumed that there was imperfect mobility between occupations $(G T, 14)$. At the extreme, each of our three sectors could have independent supplies of labor. It is more useful in addressing the modern debate over the existence of involuntary unemployment, however, to assume that, while there is no mobility between $k 1$ and $k 2$, workers in the capital-goods sectors are the more skilled and the more highly paid, and that workers in the consumption-goods sector need not be skilled. Qualified workers unable to find work in the capital-goods sectors constitute (part of) the supply of labor to the consumption-goods sector. Thus, the supply of labor in the consumption-goods sector depends on the supply and demand for labor in each of the capital-goods sectors as well as upon the real wage:

$$
L_{c}^{s}=L_{c}^{D}\left(L_{k 1}^{S}, L_{k 2}^{S}, L_{k 1}^{D}, L_{k 2}^{D}, w_{c} / p_{c}\right) .
$$

Because efficiency wages are not paid in the capital-goods sector, it can be assumed to clear in the usual manner:

$$
L_{c}^{D}=L_{c}^{S} \text {. }
$$

If it can be shown that the concept of involuntary unemployment makes sense even when there is a secondary sector which clears, it follows $a$ fortiori that the concept of involuntary unemployment makes sense when relative efficiency wages are pervasive.

\subsection{Aggregate Demand}

Assuming that the supply of labor exceeds the demand for labor in the capital-goods sector, total consumption would depend not only upon relative prices and wages, as it would in the neoclassical model, but also upon total employment in the capital-goods sector, which is rationed. ${ }^{15}$

15. Consumption multipliers arise because of this rationing just as they do in Clower's (1965) reinterpretation of the Keynesian consumption function. Were labor demand greater than labor 
Another way of putting this is that consumption depends on total current income-namely, there is a standard Keynesian consumption function:

$$
C=C\left(p_{k 1} y_{k 1}+p_{k 2} y_{k 2}+p_{c} y_{c}, p_{c}\right) \text {. }
$$

To close the model, I ignore most of the complications of Keynes's analysis of aggregate demand simply by specifying that, aside from consumption, the only other components of aggregate demand are nominal autonomous expenditures $\left(A_{k 1}\right.$ and $\left.A_{k 2}\right)$, which may be thought of as government expenditure on capital goods. All goods markets clear, so that

$$
y_{c}=C
$$

and

$$
y_{k 1}=A_{k 1} / p_{k 1} \text {, }
$$

and similarly for sector $k 2$. A more sophisticated (and more Keynesian) analysis of aggregate demand would not add anything of significance to the analysis.

\subsection{Comparative Statics}

The comparative statics of the relative-efficiency-wage model are fairly easy to explain. The model is fully laid out in the appendix. Concrete functional forms are posited, and for a particular set of parameters, an equilibrium solution and the results of several comparative static experiments are presented. The key results are precisely what Keynes leads us to expect.

Consider the case in which the supply of labor exceeds the demand for labor in the capital-goods sectors. Additional spending on capital goods-Keynes's preferred method of combating the slump (see $G T$, $116,117,119,129)$-clearly reduces unemployment in the relativeefficiency-wage model. The Keynesian prescription to expand aggregate demand works as follows. A proportional increase in $A_{k 1}$ and $A_{k 2}$ (say an increase in government expenditure) increases the demand for capital goods, driving up their prices. Because of the relativity game played by firms, $w_{k 1}$ and $w_{k 2}$ do not rise, so efficiency remains constant. The rise in

supply, consumption would depend only upon relative prices, but firms would find themselves rationed in the labor market. 
$p_{k 1}$ and $p_{k 2}$ lowers the real wage from the firms' point of view, encouraging them to hire redundant workers and to increase output. The additional wages paid to workers in the capital-goods sectors increase nominal consumption demand. Prices (and wages) rise in the consumption-goods sector to maintain market clearing. Total unemployment falls, both because of the increased demand for labor in the capital-goods sectors and because the rise in $p_{c}$ in the face of fixed nominal wages in the capital-goods sectors lowers the total supply of labor. ${ }^{16}$

A continued increase in aggregate demand reduces unemployment, until either $k 1$ or $k 2$ reaches the point at which the supply of and demand for labor are just equal. At that point, nominal wages in both sectors must rise. They rise in the sector that first becomes constrained because the short side of the market dominates. So, as Keynes understood $(G T, 3)$, the limiting case of his model was a classical model. Nominal wages rise in the other sector because firms find it profit maximizing to preserve the existing relativities. In The General Theory, Keynes argues that his two definitions of unemployment - one based on rationing, the other on the elasticity of output to aggregate demand-were in fact consistent (cf. Keynes 1973, 71, 86). In a letter to John Hicks in 1936, Keynes (1973, 74-75) clarifies the point, noting that in the short run, when labor is specialized by skill or location, inelasticity of output will be reached before each separate specialized market clears $(1973,74-75)$. This is a natural property of the model developed here.

The only prominent feature of the Keynesian account that is not found in the model as it is set out here is Keynes's recognition that nominal wages are not strictly rigid, but in fact do fall in the slump, though not in such a way as to ensure market clearing. The model could be modified in such a way that efficiency becomes a function of the state of the economy. As Keynes writes, "Labor is not more truculent in the depression than in the boom-far from it" $(G T, 9)$. With some modification, the model would allow nominal wages to rise somewhat in the boom, even before the capital-goods sectors reach full employment, and fall somewhat in the slump.

16. After The General Theory was published, Keynes $(1973,26)$ wrote that a better definition of unemployment might in fact be that unemployment exists when holding the marginal propensity to consume constant, an increase in investment increases consumption. The comparative static experiment here corresponds to a test for unemployment under that definition, and shows that, as Keynes believed, his various definitions were consistent. 


\section{The Concept of Involuntary Unemployment}

\subsection{A New Classical Objection}

"Against Keynes" is a central attitude in the new classical worldview. While it would be anachronistic to build new arguments for Keynes to rebut the anti-Keynesian positions of the new classicals, it is instructive to see how well the old arguments hold their own. Continued relevance is a fundamental rationale for history of economic thought.

The new classical macroeconomics seeks market-clearing microfoundations for macroeconomics. ${ }^{17}$ In general, new classical economists dissent from "Keynesian" macroeconomics as relying on various sorts of irrationality-contrary to the spirit of neoclassical microeconomics. The relative-efficiency-wage model shows that, at least in the labor market, such irrationality need not be associated with Keynes.

More particularly, however, the new classicals challenge the soundness of Keynes's distinction between voluntary and involuntary unemployment. This is most clearly stated by Robert Lucas:

Nor is there any reason why one would want to draw this distinction. Certainly the more one thinks about the decision problem facing individual workers and firms the less sense this distinction makes. The worker who loses a good job in prosperous times does not volunteer to be in this situation: he has suffered a capital loss. Similarly, the firm which loses an experienced employee in depressed times suffers an undesired capital loss. Nevertheless the unemployed worker at any time can always find some job at once, and a firm can always fill a vacancy instantaneously. That neither typically does so by choice is not difficult to understand given the quality of the jobs and the employees which are easiest to find. Thus there is an involuntary element in all unemployment, in the sense that no one chooses bad luck over good; there is also a voluntary element in all unemployment, in the sense that however miserable one's current work options, one can always choose to accept them. $(1978,242)$

Lucas goes on to accuse Keynes of indulging in mere wordplay in his definition of unemployment. The phrase "the existing money wage," he argues, is completely ambiguous. Unless it is defined "as the price someone else is willing to pay him for his labor . . ., what is it?" (Lucas 
$1978,242)$. And if it is defined in this way, there is no such thing as involuntary unemployment; for there is always some wage available to any worker; and, if they do not accept it, they are voluntarily unemployed.

Lucas makes the same point in a more homely way in Klamer's Conversations with the New Classical Economists . . . (1984):

KLAMER: My taxi driver here is driving a taxi, even though he is an accountant, because he can't find a job. . .

LUCAS: I would describe him as a taxi driver [laughing], if what he is doing is driving a taxi.

KLAMER: But a frustrated taxi driver.

LUCAS: Well, we draw these things out of urns, and sometimes we get good draws, sometimes we get bad draws. (40)

\subsection{A Modern Response}

The new classicals are not known to favor efficiency-wage models. Still, even in most such models, Lucas would have to say that there is no involuntary unemployment. In the relative-efficiency-wage model of section 4, the secondary sector clears and all workers are potentially workers in the secondary sector (taxi drivers); therefore, there is no involuntary unemployment. This is much like Thomas Hobbes's point that fear and liberty are consistent (1651, chap. 21). When one chooses after rationally weighing the consequences, however unpalatable, one's action is voluntary (cf. Lindbeck and Snower 1987, 7; de Vroey 1991, 19, 20).

In answering a point about an efficiency-wage model, Shapiro and Stiglitz attempt to deflect this same sort of criticism:

At one level, the issue here is just a matter of semantics. It is little different from the old story that so long as there is a competitive labor market anywhere in the economy (grape picking in California) all unemployment must be voluntary, since any individual could have moved to California ("purchased a job"). To us the fact that during the Great Depression 20 or 25 percent of the labor force in Chicago, workers who were once gainfully employed, were sitting at home, willing to work, at the going wage in Chicago, suggests a massive market failure, regardless of whether one says that, because of their decision not to migrate to California, they were voluntarily unemployed. (1987, 1215) 
This line of argument-though it strikes a responsive chord-is not entirely effective against a point such as Lucas's. It does not answer directly his charge about the ambiguity of a phrase such as the "going wage." It claims a point is merely semantic, as if that meant totally insubstantial. At heart involuntary unemployment is here defined to be that a worker is involuntarily unemployed when he is out of work and the wage exceeds the marginal disutility of his labor. And, when one asks, as Lucas does, "what sort of labor?" we must answer, "the sort the worker most wants to do if he is qualified to do it." But, as Lucas senses, this may be difficult to pin down.

And Keynes has a stronger response at his disposal.

\subsection{Keynes Anticipated Lucas}

Keynes's definition of involuntary unemployment is not that the wage exceeds the marginal disutility of labor of those out of work. This is simply a deduction from his primary definition-namely, a small rise in prices increases employment in aggregate or, equivalently, the elasticity of employment to aggregate demand is not zero (cf. Leijonhufvud 1968, 94).

Keynes's definition of involuntary unemployment, especially the first statement of it as a test of what happens when the price of wage goods rises, strikes many as extremely convoluted, and it has been the source of much confusion. However, once we interpret Keynes's labor market as a relative-efficiency-wage model, the value of such a definition becomes clear. By proposing a test of what happens to total employment, Keynes directs our attention away from the individual unemployed worker toward the work force and the economy as a whole: "men are involuntarily unemployed" (GT, 15; original italics, emphasis added) not "a man is involuntarily unemployed." Of course, if men are unemployed, some particular men must be unemployed as well; and Keynes points to exactly those people whom common sense suggests-workers who would work in their chosen profession at the going wage, but who are not offered work. If an earlier Lucas had challenged Keynes over the ambiguity of "the going wage," Keynes could merely have answered, "perform the test": consider a single market and ask, if the price of wage goods rises, would more people be employed? Or consider the economy as a whole and ask, if aggregate demand rises, would more people be employed? Those potential accountants who refuse to work as taxi drivers are involuntarily unemployed if, in a higher state of aggregate demand they 
would be employed as accountants; even those who work as taxi drivers are involuntarily unemployed as accountants if, in a higher state of aggregate demand, they were offered desks and ledgers instead of taxis. The relative-efficiency-wage model encapsulates both phenomena, which is perhaps the strongest reason for taking it to be an adequate summary of Keynes's fundamental insights.

The relative-efficiency-wage model also suggests why the proposal of those "Keynesian" critics who would surgically remove chapter 2 from The General Theory is unnecessarily drastic. Concern for relative wages can force the economy into a stable configuration below full employment. If there is a sector such as the consumption-goods sector in the model above, or like taxi-driving in Klamer's exchange with Lucas, in which the wage clears the market, then the economy will appear to be fully employed. There is malemployment in such an economy as some of the employed could be better employed. Such malemployment depends, however, precisely as Keynes suggests, on the violation of the second classical postulate (that is, on labor rationing), and his apparently convoluted definition of unemployment provides the acid test for its existence. Chapter 2, therefore, provides the firm basis for the elasticity of employment and output to aggregate demand, which is the aspect of underemployment these critics prefer to stress. Chapter 2 is neither redundant nor incoherent; it is indispensable.

Lucas and his allies revive classical modes of economic analysis. Because he knew his classical opponents intimately, Keynes tailored his definitions to answer their criticisms and, in so doing, fully anticipated new classical objections as well. In the quotation above, Lucas argues that unemployment is voluntary albeit unfortunate. Keynes understood this point of view: "A classical economist may sympathize with labour in refusing to accept a cut in its money wage, . . . ; but scientific integrity forces him to declare that this refusal is, nevertheless, at the bottom of the trouble" $(G T, 16)$. But Keynes continued, "The classical theorists resemble Euclidean geometers in a non-Euclidean world who, discovering that in experience straight lines apparently parallel often meet, rebuke the lines for not keeping straight-as the only remedy for the unfortunate collisions which are occurring. Yet, in truth, there is no remedy except to throw over the axiom of parallels and to work out a non-Euclidean geometry" $(G T, 16)$.

A metaphor perhaps more apt than Keynes's own is that the classical economists are like the Ptolemaic astronomers, who can fit their 
models to most any phenomenon, providing, of course, they can invent enough clever epicycles. Of course, Keynes is then our Copernicus, leaving plenty of room for latter-day Keplers and Newtons to correct and develop his insights. This seems to identify the new classicals with the Inquisition, cleaving to the old science, while denouncing the new, in the face of overwhelming evidence to the contrary.

\section{Appendix: The Relative-Efficiency-Wage Model}

What follows is an illustration of the model described in the text with concrete functional forms replacing the general mathematical forms presented there.

\section{Sector $k l$}

$y_{k l}=a_{11}\left(e_{k l} L_{k !}^{D}\right)^{a_{12}}$

production function

$a_{11} a_{12}\left(e_{k 1} L_{k 1}^{D}\right)^{\left(a_{12}-1\right)} e_{k 1}=w_{k 1} / p_{k 1}$

first-order condition

$L_{k 1}^{S}=c_{11}\left(w_{k 1} / p_{c}\right)$ for profit maximization

$e_{k 1}=-b_{11}+b_{12}\left(w_{k 1} / w_{k 2}^{p}\right)^{b_{13}}$

labor supply

efficiency function

$e_{k 1}^{\prime}=b_{12} b_{13}\left(w_{k 1} / w_{k 2}^{p}\right)^{\left(b_{13}-1\right)}$

if $L_{k 1}^{S}>L_{k 1}^{D}$,

$e_{k 1} / e_{k 1}^{\prime}=w_{k 1} / w_{k 2}^{p}$

Solow condition

otherwise

$L_{k 1}^{S}=L_{k 1}^{D}$

labor market clearing

$d_{11} / p_{k 1}=y_{k 1}$

goods market clearing

\section{Sector $k 2$}

$y_{k 2}=a_{21}\left(e_{k 2} L_{k 2}^{D}\right)^{a_{22}}$

production function

$a_{21} a_{22}\left(e_{k 2} L_{k 2}^{D}\right)^{\left(a_{22}-1\right)} e_{k 2}=w_{k 2} / p_{k 2}$

first-order condition for profit maximization

$L_{k 2}^{S}=c_{21}\left(w_{k 2} / p_{c}\right)$

labor supply

$e_{k 2}=-b_{21}+b_{22}\left(w_{k 2} / w_{k 1}^{P}\right)^{b_{23}}$

efficiency function

$e_{k^{2}}^{\prime}=b_{22} b_{23}\left(w_{k 2} / w_{k 1}^{P}\right)\left(b_{23}-1\right)$

if $L_{k 2}^{S}>L_{k 2}^{D}$,

$e_{k 2} / e_{k 2}^{\prime}=w_{k 2} / w_{k 1}^{P}$

Solow condition

otherwise 
$L_{k 2}^{S}=L_{k 2}^{D}$

$d_{21} / p_{k 2}=y_{k 2}$

Sector $c$

$y=a_{31}\left(L_{c}^{D}\right)^{a_{32}}$

$a_{31} a_{32}\left(L_{c}^{D}\right)^{\left(a_{32}-1\right)}=w_{c} / p_{c}$

$L_{c}^{s}=\left(L_{k 1}^{D} / L_{k 1}^{s}\right) c_{11}+\left(L_{k 2}^{D} / L_{k 2}^{s}\right) c_{21}$ $\left.+c_{31}\right)\left(w_{c} / p_{c}\right)$

$L_{c}^{s}=L_{c}^{D}$

labor market clearing

goods market clearing for profit maximization

The labor-supply function for sector $c$ (A.17) is derivative of the linear labor-supply functions in sectors $k 1$ and $k 2$. It is based on the assumption that firms in $k 1$ and $k 2$ choose the workers they actually hire uniformly from those whose reservation wage is at or below the offer wage: that is, they cannot discriminate on the basis of the reservation wage. $U$ is the conventionally calculated rate of unemployment: in this model $U=1-\left(L_{k 1}^{D}+L_{k 2}^{D}+L_{c}^{D}\right) /\left(L_{k 1}^{s}+L_{k 2}^{s}+L_{c}^{s}\right)$. The $b_{i j}$ 's are chosen to ensure that equation (7) (in the main text) is fulfilled with $w_{k 1} / w_{k 2}=1$.

Consider the four comparative static experiments presented in table 1. The parameter settings illustrate the existence of an equilibrium and the behavior of the model; they confirm the comparative static results discussed in the text. Column I is taken to be the benchmark solution, and shows that the model is not vacuous. Column II shows that when the demand parameters, $d_{11}$ and $d_{21}$, and all prices and wages (including the perceived wages) are raised proportionally, there are only nominal, not real, effects. This confirms the homogeneity of the model of degree one, demonstrating that Leontief's objection does not apply. Column III shows a coordinated symmetrical wage cut (including perceived wages) with no change in demand. This demonstrates that, were such coordination is possible, unemployment could be lowered. Column IV shows a symmetrical increase in the demand for capital goods without coordination of response (that is, initial perceived wages do not change). Actual wages do not change either and demand is increased enough so that unemployment once again falls-this time to zero. 
Hoover / Keynes's Labor Market 683

Table 1 Comparative Statics

\begin{tabular}{|c|c|c|c|c|}
\hline \multirow[b]{2}{*}{ Parameter } & \multicolumn{4}{|c|}{$\begin{array}{c}\text { Parameter Settings } \\
\text { Case }\end{array}$} \\
\hline & I & II & III & IV \\
\hline$a_{11}$ & 2.0000 & 2.0000 & 2.0000 & 2.0000 \\
\hline$a_{21}$ & 2.0000 & 2.0000 & 2.0000 & 2.0000 \\
\hline$a_{31}$ & 2.0000 & 2.0000 & 2.0000 & 2.0000 \\
\hline$a_{12}$ & 0.5000 & 0.5000 & 0.5000 & 0.5000 \\
\hline$a_{22}$ & 0.5000 & 0.5000 & 0.5000 & 0.5000 \\
\hline$a_{32}$ & 0.2500 & 0.2500 & 0.2500 & 0.2500 \\
\hline$b_{11}$ & 1.0000 & 1.0000 & 1.0000 & 1.0000 \\
\hline$b_{21}$ & 1.0000 & 1.0000 & 1.0000 & 1.0000 \\
\hline$b_{12}$ & 4.0000 & 4.0000 & 4.0000 & 4.0000 \\
\hline$b_{22}$ & 4.0000 & 4.0000 & 4.0000 & 4.0000 \\
\hline$b_{13}$ & 0.7500 & 0.7500 & 0.7500 & 0.7500 \\
\hline$c_{11}$ & 2.0000 & 2.0000 & 2.0000 & 2.0000 \\
\hline$c_{21}$ & 2.0000 & 2.0000 & 2.0000 & 2.0000 \\
\hline$c_{31}$ & 2.0000 & 2.0000 & 2.0000 & 2.0000 \\
\hline$d_{11}$ & 1.0000 & 1.1000 & 1.0000 & 1.1000 \\
\hline$d_{12}$ & 1.0000 & 1.1000 & 1.0000 & 1.1000 \\
\hline$g_{31}$ & 0.0000 & 0.0000 & 0.0000 & 0.0000 \\
\hline \multirow[t]{2}{*}{$g_{32}$} & 0.9000 & 0.9000 & 0.9000 & 0.9000 \\
\hline & \multicolumn{4}{|c|}{ Initial Conditions } \\
\hline$w_{k 1}^{P}$ & 4.0000 & 4.4000 & 3.5000 & 4.0000 \\
\hline$\hat{w_{k 2}^{P}}$ & 4.0000 & 4.4000 & 3.5000 & 4.0000 \\
\hline Variable & I & II & III & IV \\
\hline$w_{k 1}$ & 4.0000 & 4.4000 & 3.5000 & 4.0000 \\
\hline$L_{k 1}^{D}$ & 0.2500 & 0.2500 & 0.2857 & 0.3333 \\
\hline$L_{k 1}^{S}$ & 0.4900 & 0.4900 & 0.4170 & 0.3333 \\
\hline$y_{k 1}$ & 1.7321 & 1.7321 & 1.8516 & 2.0000 \\
\hline$p_{k 1}$ & 1.1547 & 1.2702 & 1.0801 & 1.3334 \\
\hline$w_{k 2}$ & 4.0000 & 4.4000 & 3.5000 & 4.0000 \\
\hline$L_{k 2}^{D}$ & 0.2500 & 0.2500 & 0.2857 & 0.3333 \\
\hline$L_{k 2}^{S}$ & 0.4900 & 0.4900 & 0.4170 & 0.3333 \\
\hline$y_{k 2}$ & 1.7321 & 1.7321 & 1.8516 & 2.0000 \\
\hline$p_{k 2}$ & 1.2702 & 1.2702 & 1.0801 & 1.3334 \\
\hline$w_{c}$ & 6.0922 & 6.7014 & 16.7870 & 12.0016 \\
\hline$L_{c}^{D}$ & 1.4773 & 1.4773 & 1.3351 & 0.9999 \\
\hline$L_{c}^{S}$ & 1.4773 & 1.4773 & 1.3351 & 0.9999 \\
\hline$y_{c}$ & 2.2049 & 2.2049 & 2.1499 & 1.9999 \\
\hline$p_{c}$ & 16.3270 & 17.9597 & 8.3727 & 24.0014 \\
\hline$U$ & 0.1953 & 0.1953 & 0.1218 & 0.0000 \\
\hline
\end{tabular}




\section{References}

Akerlof, George A. 1982. Labor Contracts as Partial Gift Exchange. Quarterly Journal of Economics 97.4:543-69.

Akerlof, George A., and Janet L. Yellen. 1986. Efficiency Wage Models of the Labor Market. Cambridge: Cambridge University Press.

Barro, Robert J., and Herschel I. Grossman. 1971. A General Disequilibrium Model of Income and Employment. American Economic Review 61.1:82-93.

. 1976. Employment, Output and Inflation. Cambridge: Cambridge University Press.

Bateman, Bradley W. 1987. Keynes's Changing Conception of Probability. Economics and Philosophy 3.1:97-119.

Blaug, Mark. 1985. Economic Theory in Retrospect. 4th ed. Cambridge: Cambridge University Press.

Carabelli, Anna M. 1988. On Keynes' Method. London: Macmillan.

Chakrabarti, Santi K. 1979. The Two-Sector General Theory Model. Delhi: Macmillan.

Chick, Victoria. 1987. Macroeconomics after Keynes. Deddington, Oxford: Philip Allan.

Clower, Robert W. [1965] 1984. The Keynesian Counter-revolution: A Theoretical Appraisal. In Clower 1984b.

- 1984a. Money and Markets. In Clower 1984b.

. 1984b. Money and Markets: Essays by Robert W. Clower. Edited by Donald A. Walker. Cambridge: Cambridge University Press.

Darity, William A., Jr., and Bobbie L. Horn. 1987a. Involuntary Unemployment Reconsidered. Southern Economic Journal 49.3:717-33.

1987b. Involuntary Unemployment Independent of the Labor Market. Journal of Post Keynesian Economics 10.2:216-24.

De Vroey, Michel. 1991. Labour Rationing, Involuntary Unemployment, Underemployment, and Malemployment: A Conceptual Elucidation. Working Paper No. 9119, Institut de Recherches Economiques et Sociales, Department des Sciences Economiques, Universite Catholique de Louvain, Belgium.

Fender, John. 1981. Understanding Keynes: An Analysis of the General Theory. Brighton: Wheatsheaf.

Fischer, Stanley. 1977. Long-term Contracts, Rational Expectations, and the Optimal Money Supply Rule. Journal of Political Economy 85.1:191-206.

Friedman, Milton. 1974. A Theoretical Framework for Monetary Analysis. In Milton Friedman's Monetary Framework. Edited by Robert J. Gordon. Chicago: University of Chicago Press.

Galbraith, John Kenneth. 1987. Economics in Perspective: A Critical History. Boston: Houghton Mifflin.

Hicks, John R. [1937] 1967. Mr. Keynes and the Classics. In Critical Essays in Monetary Theory. Oxford: Clarendon.

Hobbes, Thomas. 1651. Leviathan, or the Matter, Forme and Power of a Common- 
wealth Ecclesiastical and Civil.

Hoover, Kevin D. 1988. The New Classical Macroeconomics: A Sceptical Inquiry. Oxford: Blackwell.

Keynes, John Maynard. 1936. The General Theory of Employment, Interest and Money. London: Macmillan.

- 1937. The General Theory of Employment. Quarterly Journal of Economics 52.1:209-23.

_ [1931] 1973. The Economic Consequences of Mr. Churchill. In Keynes 1973.

- 1973. The General Theory and After: Part II Defence and Development. Vol. 14 of The Collected Writings of John Maynard Keynes. London: Macmillan and St. Martin's Press.

Klamer, Arjo. 1984. The New Classical Macroeconomics: Conversations with the New Classical Economists and Their Opponents. Brighton: Wheatsheaf Books.

Lawlor, Michael S., William A. Darity, Jr., and Bobbie L.Horn. 1987. Was Keynes a Chapter Two Keynesian? Journal of Post Keynesian Economics 9.4:516-28.

Leibenstein, Harvey. 1957. Economic Backwardness and Economic Growth. New York: Wiley.

Leijonhufvud, Axel. 1968. On Keynesian Economics and the Economics of Keynes: A Study in Monetary Theory. New York: Oxford University Press.

Leontief, Wassily. 1936. The Fundamental Assumption of Mr. Keynes's Monetary Theory of Unemployment. Quarterly Journal of Economics 51.1:192-97.

Lindbeck, Assar, and Dennis Snower. 1987. The Insider-Outsider Theory of Employment and Unemployment. Cambridge: MIT Press.

Lucas, Robert E., Jr. 1978. Unemployment Policy. In Studies in Business-Cycle Theory. Oxford: Blackwell.

Marshall, Alfred. 1920. Principles of Economics. 8th ed. London: Macmillan.

Patinkin, Don. [1956] 1965. Money, Interest, and Prices. 2d ed. Harper \& Row.

- 1982. Anticipations of the General Theory? Chicago: University of Chicago Press.

- 1987. John Maynard Keynes. In The New Palgrave Dictionary of Economics. Edited by J. Eatwell, M. Milgate, and P. Newman. London: Macmillan.

Shapiro, Carl, and Joseph E. Stiglitz. 1987. Can Unemployment Be Involuntary: Reply. American Economic Review 75.5:1215-17

Smithin, John Nicholas. 1987. The Definition of Involuntary Unemployment in Keynes' General Theory: A Note. HOPE 17.2:219-22.

Stiglitz, Joseph E. 1987. The Causes and Consequences of the Dependence of Quality on Price. Journal of Economic Literature 25.1:1-48.

Taylor, John B. 1979. Staggered Wage Setting in a Macro Model. American Economic Review 69.2:108-13.

Tobin, James. 1992. An Old Keynesian Counterattacks. Eastern Economic Journal 18.4:387-400.

Vercelli, Alessandro. 1991. Methodological Foundations of Macroeconomics: Keynes and Lucas. Cambridge: Cambridge University Press. 